\title{
Correlates of School Plant Provision and Students' Academic Performance in Government Technical Colleges in South West, Nigeria
}

\author{
Salami, Fatimat Funmilola ${ }^{1 *} \quad$ Gbenu, Jide Pius (Ph.D) ${ }^{2}$ \\ Department of Educational Management, Faculty of Education, \\ Lagos State University, Ojo, Lagos, Nigeria
}

\begin{abstract}
This study investigated the relationship between school plant provision and students' academic performance in Government Technical Colleges in South West, Nigeria. One research question as well as one hypothesis guided the study. Descriptive, correlational, and ex-post facto research designs were adopted by the study. Two research instruments comprising test item and checklist were used to gather data through both primary and secondary sources. The test item comprised of a Records Observation Format (ROF) which was used to collect data on students' academic performances in the National Business and Technical Education Board (NABTEB) examinations for the years 2014 to 2018, while the checklist was administered to 400 students in the 11 sampled Government Technical Colleges in South West, Nigeria out of a total population of 34 colleges. Data collected were analysed to answer the research question using the descriptive statistics of mean and simple percentage, while the hypothesis was tested at 0.05 level of significance, using the inferential statistics of Pearson's Product Moment Correlation Coefficient with the aid of the Statistical Package for Social Sciences (SPSS) 21.0 version for windows. The finding of the study showed that in the Government Technical Colleges in South West, Nigeria, there is no statistical significant relationship between school plant provision and students' academic performance. Also, the states of school plant provision in the colleges were poor considering the mean percentages of provision adequacies and utilisation optimalities recorded. The findings of this study therefore implied that for the results of examinations of the students to have been averagely good even with the worrisome state of plant in their various colleges except for few of the colleges where renovation of various forms have been done, an adequate provision of school plant would have resulted into much better performance than already seen. This would translate into turning out graduates who could really stand on their own having been properly engaged in practical aspects of their trades which would ensure their competencies for self-reliance.
\end{abstract}

Keywords: School Plant, School Plant Provision, School Plant Utilisation, General School Plant, Academic Performance, Government Technical Colleges.

DOI: $10.7176 / \mathrm{JEP} / 12-11-04$

Publication date: April $30^{\text {th }} 2021$

\section{Introduction}

Investing in the education of the citizens of a country in a wholesome manner is crucial to having a society that possesses the ascendancy of productive youths who hold the ability to contribute significantly to the general growth and development of the nation. Learners are bestowed with different potentials which demand to be recognised and developed, thereby leading to atttaining self-actualisation on the parts of the individuals which resultantly have positive impact on the entire society. These potentials however remain merely intrinsic values within the learners without a proper, well-organised and adequately funded system of education. Vijay (2017) defined education as a tool that improves functional and analytical ability and thereby opens up opportunities for individuals and groups to achieve greater access to labour markets and livelihoods. Education is not only an instrument for enhancing efficiency but is also an effective tool for widening and augmenting democratic participation and upgrading the overall quality of individual and societal lives.

The recognition of the importance of education as the foundation of national development triggered the provision of education in varied forms by the Nigerian government, one of which is the technical education. Technical education has been defined by various authors. It is defined as being an interwoven term with vocational education. Some authors see the two terms as being separate, thus distinguishing between their definitions, while some define both terms as one.

Okoye and Okwelle (2014) described technical education as a formal training that enables application of the techniques of applied sciences and mathematical principles for the service of humankind. Vocational and technical education is defined as "a comprehensive term referring to those aspects of the educational process involving in addition to general education, the study of technologies and related sciences, and the acquisition of practical skills, attitudes, understanding and knowledge relating to occupations in various sectors of economic and social life" (United Nations Educational, Scientific and Cultural Organization (UNESCO) In Ansah \& Kissi, 2013; UNESCO In Ayonmike, Okwelle \& Okeke, 2015; Sanusi, 2016; Nwosu \& Micah, 2017). It is therefore 
distinguishable from what one may call academic/professional training which is scholastic in nature, and aims at knowledge production. Unlike academic training, vocational and technical training targets the application of, or the practical relevance of education to the work place at lower, middle and senior personnel levels as well as management positions. It is therefore the kind of education that allows minimal difficulties in the transition from school to work, and if properly administered, reduces job-skills mismatch (Sanusi, 2016). Nwadioha cited in Ovbiagele (2015) said the terms vocational and technical education are in most cases used interchangeably. However though similar, they are not the same. Vocational education according to Nwadioha is an aspect of technical education that lays emphasis on skills acquisition and functional education for the development of the society. That is, it leads to employment in a job, trade, or occupation. Technical education on the other hand is an aspect of education which leads to the acquisition of practical and applied skills as well as basic scientific knowledge. It gives both quality and quantity of the manpower required for transformation of a country in a technical world of work.

In Nigeria, technical education is provided at secondary and post-secondary levels of education to cater for the needs of learners in order to make them self-reliant in the future, thereby serving as an avenue to reduce unemployment rate in the country. The broad goals of technical education as stressed by the Federal Government of Nigeria (FGN) in the National Policy on Education (2013) entail the:

\section{"provision of trained manpower in the applied science and technology and business, particularly at craft, advanced craft and technical levels; provision of technical knowledge and vocational skills that are necessary for agriculture, commercial and economic development; and giving training and imparting necessary skills to individuals who shall be self-reliant economically".}

The actualisation of the above goals through the acquisition of desirable skills by the students of technical colleges depends greatly on a combination of factors, one of which is school plant. School plant are referred to as the physical aspects of educational inputs or educational facilities. School plant entails all other resources aside from human resources and money in its monetary state, which are used up in the process of getting learners equipped with the required knowledge and skills. It consists of all the equipment, tools, and consumables that enable effective teaching and learning to take place within the school system. In a nut shell, school plant comprises of one out of the three Ms (Man, Money, and Material). It encompasses all the materials required for functional teaching-learning condition to be attained (Salami, 2021). The provision of school plant which include everything within the school with the exception of personnel (Olaniyonu, cited in Olaniyonu and Gbenu, 2010), is expected to meet the ever-changing demands of learners in quality (being modern) and in quantity (being adequate). Otherwise, the goals of education will generally remain mere paper tigers.

To Sanusi and Akpotu (2015), good education is defined by the quality of its inputs, a strong financial and infrastructural provision and a relevant curriculum that meets the ever changing needs of the learners and society. Good quality education is an education that provides students with the tools to deal with and find solution to the challenges confronting mankind. The authors further asserted that in a changing world, this means that what was considered good quality yesterday might not meet the standard of what may be understood as good quality today or tomorrow. The authors emphasized that this is particularly true at present if we take into consideration the rapid changes created by new technologies. The provision of adequate and modern infrastructural facilities that promote good quality impartation of science, technology and even general liberal education is considered a crucial part of a qualitative education. The authors concluded that in fact, the education that brings development is that which is well-funded, provided with state-of-the-art facilities and equipment, with well motivated and dedicated manpower to impart the science, vocational and technology-compliant curriculum that is relevant to societal and entrepreneurial needs of individuals.

A good and functional technical education is therefore defined by the quality of these inputs (school plant) among others, which are used in catering for the developmental needs and aspirations of the individual students.

Nigeria is divided into six geo-political zones, one of which is the South West which comprises of six states namely Ekiti, Lagos, Ogun, Ondo, Osun and Oyo states. The records of academic performances of students generally across the country are usually considered as criteria for determining the effectiveness or otherwise of the country's system of education. It is however noteworthy that these performances would have been the outcome of varied contributory factors, one of which is school plant provision. Alimi, Ehinola and Alabi (2012) statistically compared the academic performances of public and private senior secondary schools in Ondo state and found that despite the empirical evidence that private schools appeared to have a higher index of facilities than public schools with 68.29 and 52.42 respectively, there was no significant difference in the academic performance of students in the public and private schools sampled. Akomolafe and Adesua (2016) conducted a study on the impact of school physical facilities on students' academic performance and it was found that there was a positively significant relationship between school physical facilities and students' academic performance. Wordu and Obele (2019) researched into the relationship between school plant provision and academic 
performance of secondary school students in Tai and Eleme local government areas of Rivers State adopting both descriptive and correlational research designs. Pearson's Product Moment Correlation was used to test the hypothesis raised and it was found that a significant relationship exists between school plant provision and academic performance.

Agbonghale and Adavbiele (2018) examined the relationship between resource availability and students' academic performance in wood work in technical colleges in Delta State, Nigeria. The researcher employed correlational survey research design. With the dwindling provision of resources and the declining academic performance of students in the technical colleges, the author wondered whether a relationship existed between resource availability and students' academic performance in the colleges. With percentages, the results of the study showed that the equipment/tools in workshops were grossly inadequate in technical colleges in Delta State, Nigeria. The relationship between resource availability and students' academic performance in wood work in technical colleges was found not to be encouraging.

The goals of technical education are measurable through the academic performances of the students in either internal or external examinations. The Government Technical Colleges students' academic performances in the National Business and Technical Education Board (NABTEB) examinations reflect the functionality or otherwise of this aspect of Nigeria's secondary level of education which is assumed to be traceable to the state of school plant provision in the colleges and should therefore be an issue of concern to any educational planner.

\section{Statement of the Problem}

Generally, the state of school plant provision across all levels of education in Nigeria has been proven to be poor such as studies by Ali, Aliyu and Sunday (2013); Odu (2011); Dokubo and Dokubo (2013); and Sanusi and Akpotu (2015) which revealed that educational facilities in primary, secondary and tertiary institutions in Nigeria are inadequately provided both in quality and quantity; this study therefore assumed that the situation would not be different in the Government Technical Colleges. The overall performances of the graduates of Government Technical Colleges in the previous years in the National Business and Technical Education Board (NABTEB) examinations in Nigeria had fallen below average and the situation had been the same till November/December 2015 with 14.21 as the percentage of candidates that had five credits and above including Mathematics and English Language (Alemma-Ozioruva and Egbejule, 2016) until May/June 2017, November//December 2017 and May/June 2018 respectively when 58.75\%, 52.74\% and 59.72\% had five (5) credits and above (Mathematics and English Language inclusive). Could the improvement in performance be in connection with the provision of school plant to the colleges?

The nexus of relationship between school plant provision and students' academic performance has also been established by many researchers at the various levels of the Nigerian educational system with few studies being focused on technical education. The need to redirect the focus of researchers to this aspect of education with regard to the relationship between school plant provision and students' academic performance thus prompted this study.

\section{Purpose of the Study}

The general purpose of this study was to ascertain any possible existing relationship between school plant provision and students' academic performance in Government Technical Colleges in South West, Nigeria in the years 2014 to 2018 .

The specific purpose was to find out the state of school plant provision in Government Technical Colleges in South West, Nigeia.

\section{Research Questions}

In relation to the general and specific purposes of the study, the question that guided this study is as follows:

i) What is the state of school plant provision in Government Technical Colleges in South West, Nigeria?

\section{Research Hypothesis}

The following null hypothesis was formulated to guide the study in order to ascertain the existing relationship between school plant provision and students' academic performance in Government Technical Colleges in South West, Nigeria.

$\mathrm{H}_{01}$ : There is no significant relationship between school plant provision and students' academic performance in Government Technical Colleges in South West, Nigeria.

\section{Methodology}

The research designs adopted for this study were descriptive, correlational and ex-post facto designs. The study was descriptive as it described the state of school plant in the Government Technical Colleges in South West, Nigeria in terms of their provision. It employed a correlational design by establishing any possibly existing 
relationship between the variables studied. It was also an ex-post facto study as it made use of past NABTEB results to determine students' academic performance, and considered already existing facilities (school plant), the variables which could not be manipulated.

The study population included all the 34 government technical colleges in South West, Nigeria as presented in the table below.

Table 1: Number of Government Technical Colleges (GOTECOs) in South West,Nigeria

\begin{tabular}{|l|l|}
\hline State & Number of Government Technical Colleges \\
\hline Ekiti & 4 \\
\hline Lagos & 5 \\
\hline Ogun & 7 \\
\hline Ondo & 4 \\
\hline Osun & 9 \\
\hline Oyo & 5 \\
\hline Total & 34 \\
\hline
\end{tabular}

Source: National Board for Technical Education (NBTE, 2018)

One college each was selected in Ekiti and Ondo states, two colleges were selected in each of Lagos, Ogun, and Oyo states, while three colleges were selected in Osun state, using a proportionate random sampling technique since they have unequal numbers of colleges. Proportionate random sampling technique was further applied to select the students' sample size in each of the colleges across the states, also due to unequal number of students studying the chosen trade courses. The sample size selected in each state is shown in the table below.

Table 2: Selected Sample Size in Each State in South West, Nigeria.

\begin{tabular}{|c|c|}
\hline State & Sample Size \\
\hline Ekiti & 40 \\
\hline Lagos & 80 \\
\hline Ogun & 80 \\
\hline Ondo & 20 \\
\hline Osun & 100 \\
\hline Oyo & 80 \\
\hline Total & 400 \\
\hline
\end{tabular}

Two instruments which included a test item and a checklist were used to gather data for this study. The test item for which a Records Observation Format (ROF) titled Records Observation Format on Government Technical Colleges Students' May/June NTC Examination Overall Academic Performance was designed by the researcher was used to summarise the data on academic performance for the study. May/June NTC Examination Results for the years 2014 to 2018 thus represented the test item. This provided data on students' academic performance, considering students that had 5 credits and above with or without English Language and Mathematics. The checklist contained a list of ten school plant, requesting the respondents to tick the extent of provision of each of the plant under the response options - Very Well Provided (VWP); Well Provided (WP); Fairly Provided (FP); Rarely Provided (RP); and Not Provided at All (NPA). The response options VWP and WP were further categorised as the components of Adequate Plant Provision (APP), the response options FP and RP were categorised as the components of Inadequate Plant Provision (IPP), while the response option NPA was the component of Plant Not Provided (PNP). The average percentage of each category thus represented the school plant provision index in each of the states in South West, Nigeria.

The checklist was subjected to reliability test using Cronbach Alpha's Reliability Coefficient. The reliability coefficient obtained was 0.825 which ascertained that the checklist was substantially reliable for the study. The reliability of NTC Examination results was however taken to have been established, being an examination conducted by a recognised and well established standardised examination body, NABTEB. The ROF used to summarise the already existing data in this regard was therefore adjudged reliable.

Mean and simple percentage were used to analyse the data gathered on school plant provision to answer the research question while Pearson's Product Moment Correlation Coefficient (PPMC) analysis was used to test the formulated hypothesis with the aid of Statistical Package for Social Sciences (SPSS) 21.0 version at 0.05 level of significance.

\section{Results}

Analysis of Research Question

What is the state of school plant provision in Government Technical Colleges in South West, Nigeria? 
Table 3:Descriptive Statistical Analysis on School Plant Provision in Government Technical Colleges in Each State in South West, Nigeria

\begin{tabular}{|l|l|l|l|l|l|l|l|}
\hline \multirow{2}{*}{ State } & \multicolumn{7}{c|}{ \% Provision } \\
\cline { 2 - 8 } & VWP & WP & APP & FP & RP & IPP & NPA (PNP) \\
\hline Ekiti & 40.00 & 5.00 & 45.00 & 29.00 & 25.00 & 54.00 & NIL \\
\hline Lagos & 34.38 & 23.13 & 57.51 & 25.38 & 7.25 & 32.63 & 8.38 \\
\hline Ogun & 28.63 & 9.63 & 38.26 & 15.25 & 5.25 & 20.50 & 40.00 \\
\hline Ondo & 19.5 & 20.00 & 39.50 & 0.50 & 17.00 & 17.50 & 40.00 \\
\hline Osun & 13.67 & 11.33 & 25.00 & 19.17 & 16.58 & 35.75 & 38.75 \\
\hline Oyo & 32.38 & 24.88 & 57.26 & 12.50 & 9.75 & 22.25 & 19.75 \\
\hline $\begin{array}{l}\text { Grand Percentage } \\
\text { Provision }\end{array}$ & & 43.76 & & & 30.44 & 24.48 \\
\hline
\end{tabular}

Table 3 revealed the average percentage state of school plant provision in each state in South West, Nigeria. In Ekiti state, adequate plant provision index was $45 \%$, inadequate plant provision index was $54 \%$, while none of the school plant was not provided. Lagos state had an adequate plant provision index of $57.51 \%$, an inadequate plant provision index of $32.63 \%$, while $8.38 \%$ represented the plant not provided index in the state. $38.26 \%$ represented the adequate plant provision index in Ogun state, the inadequate plant provision index in Ogun state stood at $17.5 \%$, while the plant not provided index was $40 \%$. Ondo state had adequate plant provision of $39.5 \%$, inadequate plant provision of $17.5 \%$, while $40 \%$ of the school plant was not provided in Ondo state. Osun state had adequate plant provision index of $25 \%$, inadequate plant provision index of $35.75 \%$, while the plant not provided was $38.75 \%$. The adequate plant provision, inadequate plant provision, and plant not provided indices in Oyo state were $57.26 \%, 22.25 \%$, and $19.75 \%$ respectively.

\section{Test of Hypothesis}

Ho1: There is no significant relationship between school plant provision and students' academic performance in Government Technical Colleges in South West, Nigeria.

Table 4: Pearson's Product Moment Correlation Analysis of Relationship between School Plant Provision and Students' Academic Performance in Government Technical Colleges in South West, Nigeria.

\begin{tabular}{|ll|l|l|}
\hline & & School_Plant_Provision & Academic_Performance \\
\hline \multirow{3}{*}{ School_Plant_Provision } & Pearson Correlation & 1 & -.058 \\
& Sig. (2-tailed) & & .672 \\
& $\mathrm{~N}$ & 400 & 55 \\
& Pearson Correlation & -.058 & 1 \\
Academic_Performance & Sig. (2-tailed) & .672 & \\
& $\mathrm{~N}$ & 55 & 55 \\
\hline
\end{tabular}

From the table above, it could be inferred that there is no statistical significant relationship between school plant provision and students' academic performance $(r=-.058, p>.05)$. Besides, the Pearson's Product Moment Coefficient is negative which implies an inverse relationship between school plant provision and students' academic performance. The null hypothesis which states that there is no significant relationship between school plant provision and academic performance is therefore accepted.

\section{Discussion}

Logically, an adequate provision of school plant gives room for proper acquisition of skills and knowledge as it avails a learner the opportunity to explore better and discover the rudiments of the learning contents he engages in while he does not dwell much in imagination. The state of school plant provision in Government Technical Colleges could be said to be poor on a general note as only $43.76 \%$ grand adequate plant provision was recorded on the average; while inadequate plant provision and plant not provided both summed up to $54.92 \%$. On the relationship between school plant provision and students' academic performance however, the finding of this study revealed that no significant relationship is found to exist between school plant provision and students' academic performance across the Government Technical Colleges in South West, Nigeria. This is in line with the findings of Alimi et al (2012) who found no significant difference in the academic performance of students with higher index of facilities and those with lower index of facilities, therefore concluding that no relationship was found to exist between facilities provision and students' academic performance. This study finding however disagreed with the findings of authors such as Ali et al (2013), Ejieh, Fadipe \& Ajadi (2014), Akomolafe \& Adesua (2016), and Wordu \& Obele (2019) who established that a significant relationship was found to exist between school plant provision and academic performance. This difference in findings could have resulted from the aspect of education considered as this study focused on technical education at the secondary level of the 
Nigerian education system while most of the authors hitherto mentioned focused their studies on the general aspect of the secondary level of education in Nigeria.

\section{Conclusion}

It could be concluded from this study that though school plant provision is an important aspect of a student's success in terms of academic performance, the state of school plant provision may however not have effect on students' academic performance in schools such as the Government Technical Colleges as this study revealed, which might have resulted from factors not captured by this study. Such factors may include among others, the extent of relevance of the school plant in the colleges to the students' learning contents and the frequency of students' engagement in practical lessons in comparison to theories.

\section{Recommendations}

Based on the findings of this study, the following recommendations were made.

(1) Conduct of conferences at state levels on technical education which involves people from the grassroots to deliberate on the state of school plant in the Government Technical Colleges and ways to collectively improve the conditions of these colleges generally.

(2) Provision of more functional workshops with modern plant, equipment, tools and materials by the state governments to the Government Technical Colleges across the country to enable higher engagement of students in practical lessons.

(3) Active involvement of other stakeholders of technical education such as private companies, parents and philanthropists in the provision of school plant to the Government Technical Colleges in order to effectively attain the goals of technical education.

(4) Government making functional plan for special intervention fund to equip the Government Technical Colleges, and separately design a special plan for the implementation of the programme so as to pay sufficient and unique attention to it as an inevitable means to achieve self-reliance through our educational system.

(5) A deliberate effort by the policy makers to boost the image of the government technical colleges in order to increase enrolments in the colleges, thereby serving as an enhanced source of revenue, the impact of which would be an increased provision of school plant to the government technical colleges. This could be done by making NABTEB result a requirement for admission into universities by all prospective engineering students, as this will also be a foundational skill building passage for the students.

\section{References}

Agbonghale, G.O. \& Adavbiele, J.A. (2018). Relationship between resource availability and academic performance of students in wood work in technical colleges in Delta state, Nigeria. European Centre for Research Training and Development UK, 6(2), 14-25

Akomolafe, C.O. \& Adesua, V.O. (2016). The impact of physical facilities on students' level of motivation and academic performance in senior secondary schools in South West, Nigeria. Journal of Education and Practice, 7(4), 38-42

Alemma-Ozioruva, A. \& Egbejule, M. (2016). NABTEB releases 2015 exam results. Retrieved 24/12/2018 from http://m.guardian.ng

Ali, H., Aliyu, O. \& Sunday, O.L. (2013). Provision and management of school plant as correlate of science students' academic performance. Journal of Education and Practice, 4(14)

Alimi, O.S., Ehinola, G.B., \& Alabi, F.O. (2012). School types, facilities and academic performance of students in secondary schools in Ondo State, Nigeria. International Education Studies, 5(3), 44-48

Ansar, S.K. \& Kissi, E. (2013). Technical and vocational education and training in Ghana: a tool for skill acquisition and industrial development. Journal of Education and Practice, 4(16), 172-180

Ayonmike, C.S., Okwelle, P.C., and Okeke, B.C. (2015). Towards quality technical vocational education and training programmes in Nigeria: Challenges and improvement strategies. Journal of Education and Learning, 4(1): 25-34

Dokubo, C. \& Dokubo, I.N. (2013). Identifiable problems inhibiting the effective management of vocational education programme in Nigerian universities. European Scientific Journal, 9(22), 1857

Ejieh, M.U.C., Fadipe, O.J. \& Ajadi, T. (2014). School plant management. A Printed Course Guide on EDA 713 of the National Open University of Nigeria. pg 112

Federal Government of Nigeria (2013). National policy on education. Abuja: NERDC Press

Nwosu, J.C. \& Micah, E.M. (2017). Technical and vocational education and training as a tool for national sustainable development in Nigeria. The International Journal of Social Sciences and Humanities Invention, 4(9): 3983-3988

Odu, O.J. (2011). Reappraising the workskill requirements for building technology education in senior secondary school for optimum performance in Nigeria. European Journal of Applied Sciences, 3(2), 46-52 
Okoye, K.R.E. \& Okwelle, P.C. (2014). Technical vocational education and training (TVET) as intervention mechanism for global competitiveness: Perspectives from Nigeria. Developing Countries Studies, 4(4), 8591

Olaniyonu, S.O.A. \& Gbenu, J.P. (2010). School plant planning \& maintenance. Lagos: MICODEX Printers

Ovbiagele, A.O. (2015). Vocational education for socioeconomic and technological development of Nigeria. Global Journal of Interdisciplinary Social Sciences (GJISS), 4(4):15-18

Salami, F.F. (2020). Effect of school plant provision and utilisation on students' academic performance in government technical colleges in south west, Nigeria. IOSR Journal of Research \& Method in Education (IOSR-JRME), 11(1):28-36

Sanusi, A.R. (2016). The potential of vocational and technical education in addressing Nigeria's temporary socio-economic and political challenges. https://ssrn.com

Sanusi, F.A. \& Akpotu, N.E. (2015). The Nigeria education system and vision 20:2020: Acritical development planning perspective. International Journal of Educational Administration and Policy Studies, 7(2),26-38

Vijay, P.G. (2017). Technical and vocational education and training (TVET) system in India for sustainable development. Centre for Innovations. www.educationinnovations.org

Wordu, H. \& Obele, O.D. (2019). School palnt provision and academic performance of secondary school students in Tai and Eleme local government areas, Rivers State. International Journal of Innovative Education Research, 7(1), 7-14 